\title{
THE ROAD TO CHAGHI: A HISTORICAL PERSPECTIVE ON PAKISTAN'S NUCLEAR PROGRAM
}

\author{
Muhammad Ali ${ }^{*}$ \\ Suwaibah Qadri** \\ Rizwana Jabeen ${ }^{* * *}$
}

\begin{abstract}
Nuclearization of South Asia always remains the most imperative concern for the international community particularly when In May 1998, India and Pakistan tested their nuclear devices which plunged South Asia into a relentless nuclear arms race. Since then, the nuclearization of South Asia has been a reality but the region is as insecure as it was before. Historically, Pakistan's nuclear program has been a subject of contention with the Western world. Pakistan has worked hard and successfully to build diverse nuclear capabilities. It will preserve these capabilities for the predictable future as a necessary deterrent against perceived existential threats from India. The objective of this study is to provide historical background of the initiatives undertaken by Pakistan towards the development of its nuclear program and highlight the major challenges and hurdles that stood in the way of achieving this goal. Paper conclude that under the present turbulent regional and international environment, Pakistan should carefully weigh its options to become an internationally acceptable normal nuclear state without compromising its genuine security concerns. It is hoped that the finding of this qualitative work would not only facilitate scholars and experts of international relations, but also be a massive contribution for the students in this field.
\end{abstract}

Keywords: Nuclear non-Proliferation, South Asia, Pakistan, Nuclear Doctrine and CTBT

\section{Introduction}

Nuclear proliferation has become an important issue in international relations due to its many fold implications. It has not only affected individual countries but the whole world order has been affected by it. There was a time when nuclear proliferation and the acquisition of nuclear power were considered to be a domain of super powers. But many of the developing countries have challenged the super power dominance in the field of nuclear power in the last few decades. Since 2016, nine states - the United States, Russia, the United Kingdom, France, China, India, Pakistan, Israel and the North Korea)-possessed approximately 15850 nuclear weapons, of which 4120 were deployed with operational forces. (See table 1).

\footnotetext{
${ }^{*}$ Muhammad Ali, Ph.D. Associate Professor Department of Political Science, University of Karachi ${ }^{* *}$ Suwaibah Qadri, Ph.D. Visiting Faculty Department of Political Science, University of Karachi

${ }^{* * *}$ Rizwana Jabeen, Lecturer, Department of International Relation, Federal Urdu University Karachi
} 


\begin{tabular}{|l|c|r|r|r|}
\hline \multicolumn{7}{|c|}{ Table One: WORLD NUCLEAR FORCES 2016} \\
\hline Country & $\begin{array}{c}\text { Year of first } \\
\text { nuclear test }\end{array}$ & $\begin{array}{c}\text { Deployed } \\
\text { Warheads }\end{array}$ & $\begin{array}{c}\text { Other } \\
\text { warheads }\end{array}$ & $\begin{array}{c}\text { Total } \\
\text { Inventory in 2016 }\end{array}$ \\
\hline USA & 1945 & 1930 & 4870 & 6,800 \\
\hline USSR & 1949 & 1790 & 5,210 & 7,000 \\
\hline UK & 1952 & 120 & 95 & 215 \\
\hline France & 1960 & 280 & 20 & 300 \\
\hline China & 1964 & - & 270 & 270 \\
\hline India & 1974 & - & 130 & 130 \\
\hline Pakistan & 1998 & - & 140 & 130 \\
\hline Israel & & - & 80 & 20 \\
\hline North Korea & 2006 & - & 10 & $\mathbf{1 4 , 9 5 5}$ \\
\hline Total & & $\mathbf{4 1 2 0}$ & $\mathbf{1 1 , 2 7 5}$ &
\end{tabular}

Source: SIPRI Yearbook $2018^{1}$

\section{Nuclearization in Pakistan}

Nuclearization remains the most important concern for the major powers as regards the South Asian security scenario, particularly when the two newest entrants to the nuclear club have an adversarial relationship. In the month of May 1998, both India and Pakistan conducted their respective series of nuclear tests and declared themselves as the sixth and seventh nuclear powers respectively. It may be added that the nuclearization in South Asia has further added to these issues and problems as South Asia has been a conflictridden region. According to the SIPRI 2018 Yearbook, India and Pakistan are increasing the size and sophistication of their nuclear arsenals. Both countries are developing and deploying new types of nuclear-capable ballistic and cruise missile and both are increasing their military fissile material production capabilities. India and Pakistan have 100-120 and 110-130nuclear weapons respectively. Based on Pakistan's performance over the past two decades, it is estimated that its stock could possibly grow to 220-250 warheads by 2025 , making it the world's fifth-largest nuclear weapon country and first in South Asia ${ }^{2}$ The paper attempts to evaluate Pakistan's nuclear force so as to determine the extent to which it can adequately maintain its level of "minimum nuclear deterrence". In regard to understanding the present nuclear policy of Pakistan, a comprehensive historical analysis of the program is discussed below.

\footnotetext{
${ }^{1}$ Global nuclear weapons: downsizing but modernizing https://www.sipri.org/media/press-release/2018/globalnuclear-weapons-downsizing-modernizing (access on 12 June 2018)

All estimates are approximate and are as of January 2018. Totals do not include figures for North Korea.

Source: SIPRI Yearbook 2018

${ }^{2}$ Hans M. Kristensen \& Robert S. Norris ,Pakistani nuclear forces, 2016 Pages 368-376 | Published online: 31 Oct 2016

http://www.tandfonline.com/doi/full/10.1080/00963402.2016.1241520 (access on 12 June 2017)
} 


\section{Establishing a Nuclear Program: 1956 to 1974}

Although Pakistan formally opted for a nuclear weapons program in the 1970s, the Indiacentric bias of its nuclear weapons policy has a longer history. The division of British India into two independent states in August 1947 was accompanied by large-scale communal clashes resulting in mass casualties as Hindus and Muslims fled across the newly created international border. Soon thereafter, war with India followed over the disputed territory of Jammu and Kashmir, thus reinforcing bilateral hostility between Pakistan and India. While India embarked on an ambitious nuclear program soon after independence, Pakistani administration was initially disinterested in following suit. The relationship with the US was considered sufficient by Pakistani decision-makers to offset the perceived Indian threat and to counterbalance India's regional and international standing. Although the Pakistani civil and military leadership showed little interest in acquiring nuclear weapons, a nascent indigenous nuclear scientific establishment did emerge after the creation of the Pakistan Atomic Energy Commission in 1956. Some help also came from the American side which trained hundreds of Pakistani nuclear scientists under such programs as Atoms for Peace and by providing Pakistan with a small nuclear research reactor.

By the decade of the 1960s, the rapid growth of India's nuclear weapons infrastructure, which included heavy water and research reactors led to an internal debate within Pakistan regarding the options available for its nuclear development. In Gen. Ayub Khan's military cabinet, Foreign Minister, Zulfiqar Ali Bhutto was amongst the most enthusiastic of nuclear advocates. By the late-1960s, local, regional and international imperatives further changed Pakistani thinking on a nuclear weapons program. The 1965 war and its aftermath had a significant impact on Pakistani perceptions of nuclear weapons. A US arms embargo imposed during the 1965 war on both Pakistan and India deprived Pakistani US- equipped military of its main source of conventional weapons. As the conventional balance continued to tilt in India's favor, the rapid expansion of India's nuclear infrastructure also heightened Pakistani concerns about India's nuclear intentions. Therefore, Pakistan's refusal to sign the NPT in 1968, following India's rejection of the same clearly indicated an increased interest within Islamabad in acquiring nuclear weapons.

After Pakistan's defeat in the Indo-Pak war of 1971 and the secession of East Pakistan with India's direct intercession, powerful factions of the Pakistani military replaced General Yahya Khan, and Zulfiqar Ali Bhutto was appointed as President and then as Prime Minister of the country. The trauma of a humiliating military defeat and India's role in the creation of Bangladesh reinforced Pakistani hostility towards India and enhanced perceptions of threat from an aggressive, expansionist foe. Bhutto adopted a nuclear weapons program to counter the perceived Indian threat and to simultaneously retain the military's goodwill. At a meeting of high-level military and civil bureaucrats and scientists in Multan on January 20, 1972, Bhutto disclosed his intentions to formally launch a nuclear weapons program; a decision that was strongly supported by the military high command and the civil bureaucracy. Bhutto and the military's resolve to acquire nuclear weapons capability was reinforced by India's detonation of a nuclear device in May 1974. 
A close look at the nuclear development programs of Pakistan and India exhibit a stark disparity of motives and commitments. In the case of Pakistan, the country followed nuclear abstinence for almost a quarter of a century. It was only after the debacle of 1971, when as a prelude to Indian military intervention in East Pakistan; among other factors, resulted in the surrender of eastern half of the country, that a dire need was felt for reappraisal of the void in nuclear development of the country. Right from its inception, India attached huge significance with its nuclear program. Not only did nuclear weapons provide a means for attaining great power status; but the ensuing rivalry with China further spurred its program.

\section{The Road To Nuclearization: 1974-1998}

India conducted nuclear test in 1974 at Pokhran and called the test a "Peaceful Nuclear Explosion" (PNE), while impishly christening it the "Smiling Buddha". This event henceforth changed the political scenario of South Asia. Alarmed by the Indian nuclear explosion as a serious threat to its security, Pakistan soon embarked upon its own nuclear course. The west instead of imposing punitive measures against India for flouting the non-proliferation regime accepted Indian claim that the explosion was a PNE. Rather than penalizing India in any way, the US Secretary of State Henry Kissinger declared that Washington would continue the shipment of nuclear fuel even without new assurance from New Delhi that they would not use it in producing any further nuclear devices. ${ }^{3}$ In fact, the west put pressure not on New Delhi but on Islamabad. Pakistan, nevertheless, began intense efforts to develop its nuclear program and soon after Z.A Bhutto's appointment as the country's President, acquired its first reactor from Canada in 1972. Bhutto reacted strongly to Indian nuclear tests and vowed the development of Pakistan's own "nuclear capability". He said the famous words "we will defend our country using any means necessary and build a nuclear capability second to none. We will eat grass for 1000 years, if we have to, but we will get there". ${ }^{4}$ In the meantime, Pakistan proposed the establishment of a Nuclear Weapons Free Zone (NWFZ) in the region in 1974. When this proposal was rejected by India, Pakistan signed a contract with France in October 1974, for the construction of a reprocessing plant at Chashma.

Since Pakistan had neither the technological nor the economic resources to create the necessary infrastructure for an ambitious nuclear energy program, it was clear that the extracted plutonium would be diverted for military purposes. In September 1977, the US discontinued military and economic aid to Pakistan when the latter refused to call off its deal with France. The UK, at this time, also advised Islamabad to cancel the deal with Paris. Soon after, swallowing its world renowned national pride, France gave into US pressure and decided to renege on the contract. In 1979, under the Symington Amendment, the US cut off all of its aids to Pakistan. Paradoxically, India and Israel were exempted from the new Amendment even when New Delhi began to enrich uranium in the 1980s. Using its diplomatic influence, it campaigned against the transfer of technology to Pakistan, as the latter was propagated to be producing an "Islamic bomb."

\footnotetext{
${ }^{3}$.Naveed Ahmed Tahir, ed, European Union-Asia Relations in the Twenty First Century, (Karachi: HannsSeidel Foundation, 2001), p.230.

${ }^{4}$.Shahid Amin, Pakistan's Foreign Policy, (Karachi: Oxford University Press, 2010),p.78
} 
The constant allegations by the West, that Pakistan was pursuing a clandestine nuclear weapons program stopped abruptly when the need arose for the US and its allies to recruit Pakistan as a frontline state to counter the USSR's invasion of Afghanistan in December 1979. For as long as the anti-Soviet jihad lasted, the US President felt no hesitation in issuing the annual certification required by congress that Pakistan was not trying to develop nuclear weapons, although US legislation forbade military and economic assistance to countries that were trying to develop nuclear weapons. ${ }^{5}$

Furthermore, Pakistan was re-declared as a cornerstone in US foreign policy as it was a front line state in the containment of communism. An aid worth US\$ 32 million and 40 F16 fighters (to be delivered from 1981-87) was directed towards Pakistan during this time. However, threats regarding enrichment of Uranium to weapon-grade level continued, but Pakistan kept firmly denying the reports and assured that the program was intended to produce nuclear weapons. India officially affirmed its right to produce nuclear weapons, and successfully launched a four-stage rocket, of its own design, to place a satellite into orbit $^{6}$. As a result, Islamabad was alarmed by India's nuclear and aerospace program, large weapons purchases from the USSR, and the attempts to expand its armament industry. Tension was somewhat defused in June 1981, when both countries agreed that the parameters of their defense requirements should be fixed and that both sides maintain ratio of arms levels. In late eighties, Pakistan while conceding that its scientist had achieved nuclear technology reaffirmed its resolve to refrain from using the technology for building nuclear weapons and to use it for peaceful purposes, especially to meet the worsening situation in the energy production sector. In 1984, Washington received reports that Pakistan had succeeded in acquiring the capability of enrichment of Uranium to weapon-grade level at the nuclear facilities at Kahuta. Pakistan also did not officially deny it. Economic aid to Pakistan, which was resumed in the wake of the Soviet intervention in Afghanistan, was again cut off following the withdrawal of the Soviet forces from Afghanistan in 1989. This major departure in US policy was caused by many factors. Pakistan had suffered a relative loss of strategic importance after Soviet withdrawal from Afghanistan. President Bush, soon after the Gulf War of 1991, had outlined future foreign policy agenda in the changed world and one of these guidelines was of full US support to the efforts aiming at arms control, specially the aims of NPT. The slash in aid to Pakistan also marks the culmination of Israeli and Indian propaganda against Pakistan's nuclear program. In the context of an ideological conflict, an "Islamic Bomb" could pose threat to US designs in the world. That is why; US also expressed fears that Pakistan may transfer nuclear technology to fellow Islamic countries (especially Iran) and thus lead to a potentially strong challenge from the Muslim countries. Therefore, US and the European countries demanded Pakistan to roll back its nuclear program and sign the NPT. The US imposed sanctions on Pakistan under the Pressler Amendment. Islamabad reacted strongly to the sanctions and called it an unjust move. In March and June 1994, the Pakistani Prime Minister Benazir Bhutto described India's Prithvi missile test, as

\footnotetext{
${ }^{5}$.Naveed Ahmed Tahir, ed, A Survey of EU-Pakistan Relations in the Contemporary Regional \& International Setting: Political, Security, Economic and Development Aspects,

(Karachi: University of Karachi Press, 2002),p.116

6. B.H Farmer, 2009,The Europa Regional Surveys of the World, (London: Routledge, 2008), p. 456.
} 
'provocative' and warned of a missile race in the region. ${ }^{7}$ The situation further deteriorated in August 1994 by public statement made by former Prime Minister Nawaz Sharif that Pakistan possessed an atomic bomb and was prepared to use it against India. Pakistani officials were quick to explain that, although Pakistan had acquired the nuclear capability but it would restrict the use of nuclear technology to peaceful purposes. ${ }^{8}$

In a dramatic move Nawaz Sharif confirmed Pakistan procession of a nuclear device. He claimed to have made this statement to deter the Indian aggressive posture after its acquisition of the missile useable for launching a nuclear warhead. It was also hoped that the US would now treat both India and Pakistan at par as both have officially declared nuclear capability. Subsequently, the US ambassador to Pakistan acknowledged that the US had never demanded rolling-back of Pakistan's nuclear program. However, the US President on September 23, 1994 stated that the US policy towards non-proliferation in South Asia focused on gradual elimination of the programs of both India and Pakistan.

In June1997, the Indian government announced that it had successfully tested its new Prithvi intermediate-range nuclear missile capable of carrying a nuclear payload that could target deep within Pakistan or China. India's development of nuclear tipped missiles had started arms race in the region. Pakistan responded on April 14 and 15 1998, by testing two advanced nuclear-capable ballistic missiles of its own. This was certainly not calculated to encourage warmer relations with the right wing Bharatiya Janata Party (BJP) that had come to power in India in March $1998 .^{9}$

\section{Second Indian Nuclear Explosions 1998}

On May 11, 1998, the newly elected government declared that it had tested three nuclear detonations and two day later another two tests had taken place at Pokhran in the northern state of Rajasthan. India's nuclear explosions for the second time came as a high surprise to the whole world. Even the United States did not predict about it. ${ }^{10}$ According to Indian PM Vajpayee (1998-2004) India considered the tests necessary to ensure India's security. Though Pakistan is considered as a main menace to its security, India has believed that its quest for nuclearization should be seen in a wider perspective. India's larger security risks arise from China because of historical border disputes and also because the PakChina axis endanger India's security. ${ }^{11}$ Immediately after the tests were conducted, few world powers including Australia, Germany, Japan, and the United States, imposed a range of economic and trade sanctions against India. The World Bank also called off a meeting that was scheduled to meet in June to discuss economic assistance to India. Some of these countries withdrew their ambassadors to New Delhi for consultations on the policy implications of the new development. The Chinese government strongly condemned the tests, urging countries around the world to pressurize New Delhi to end

\footnotetext{
${ }^{7}$.B.H Farmer, 2009, The Europa Regional Surveys of the World, Op.Cit., p.458

${ }^{8}$. www.southasianmedia.net

9. B.H Farmer, 2009, The Europa Regional Surveys of the World, Op.Cit.,p.456.

${ }^{10}$. B.C Upreti, Contemporary South Asia,(New Delhi: Kalinga Publication ,2004), p.119

${ }^{11}$. B.C Upreti, Contemporary South Asia, Op.Cit., pp.120-121
} 
its nuclear program. However, France, Russia, and the United Kingdom, (all nuclear states) refrained from imposing sanctions on India. ${ }^{12}$

Soon after the Pokhran tests, the US, the EU, Japan and other countries started putting immense pressure on the Nawaz Sharif's second regime (1997-1999) against a nuclear test. There were hints that if Islamabad desisted from nuclear testing its huge foreign debts, that were crippling its economy, could be waived. However, all the promises from the West of political support and economic assistance appeared vague in view of Pakistan's security concerns. ${ }^{13}$ The US also did not show great enthusiasm in improving Pakistan's economy or to strengthening its conventional military capabilities which could counterbalance India's nuclear weapons. Undoubtedly Indian tests posed a severe security challenge to Pakistan. With the widening disparity in conventional weapons between the two countries, New Delhi's nuclear actions severely changed the strategic balance of power in the region. The challenge to Pakistan was "to come out of the closet" if it really had the capacity to build a device. Indian leaders' statements became increasingly aggressive during this period. India even warned Pakistan to vacate Azad Kashmir. Interior Minister of India, Lal Krishna Advani issued the following menacing statement: "India's bold and decisive step to become a nuclear weapon state has brought about a qualitative new stage in Indo-Pakistan relations, particularly in finding a solution to the Kashmir problem". ${ }^{14}$

Such situation could lead to misadventure in the sub-continent. Consequently, Pakistani politicians, especially the rightist parties, Pakistani public opinion as well as military and bureaucracy, which are highly influential in decision- making process, applied strong pressure on the government in favor of the tests. ${ }^{15}$ The response of the international community had not been very promising towards Pakistan in the wake of Indian nuclear tests. It was deeply disappointed at the tame response of the international community. The US had failed to persuade G-8 countries to a straight forward response against India. While Japan and Canada supported the US, France and UK refused to go along. While the G- 8 was divided Russia opposed sanctions or any other strong measures in G-8 meetings. When the Under-Secretary of State of America, Strobe Talbott came to dissuade Islamabad from conducting a nuclear test, it had no political, economic or security package to offer which could address Pakistan's security concerns. At best, US could only offer not to impose sanctions, a possible release of the blocked F-16 planes over a two-year period, repeal of the Pressler Amendment subject to approval by US Congress, restoration of military-tomilitary contacts and vague promises of enhanced economic support through the international loaning agencies. This package did not include security guarantees against conventional or nuclear attack by India, resolution of the Kashmir issue and restoration of security and economic relationship and resumption of military sales to Pakistan.

${ }^{12}$. Keesing's Record of World Event, News Digest, June 1998.Vol.44, pp.42-43

${ }^{13}$.Dawn, May 20,1998

${ }^{14}$. Dawn, May 19, 1998.

${ }^{15}$. Naveed Ahmed Tahir, ed, A Survey of EU-Pakistan Relations in the Contemporary Regional

\& International Setting: Political, Security, Economic and Development Aspects,, Op.Cit., p.240 
In such a case, it was felt that only a tangible display of nuclear power and not mere rhetoric of the country's ability to defend its security concerns would restore the strategic balance in the South Asia. Pakistan detonated five nuclear devices on28 May 1998 in Chaghi (Baluchistan). Two days later, Islamabad tested one more nuclear warhead. ${ }^{16}$ Soon after these tests, Prime Minister Nawaz Sharif said: "We have settled the account of the nuclear blasts by India, for the safety of our nation. What happened in Hiroshima and Nagasaki would not have happened if Japan had a nuclear capability. The American nuclear capability that forced Japan to declare defeat in the World War II", he added in explaining his rationale. ${ }^{17}$

Pakistan's nuclear program has been Indo-centric. Pakistan believes that it is necessary for her to counterbalance India's position in South Asia. Pakistan perceives a threat from India to its security and identity. Therefore, Pakistan's nuclear program is a defense against threats to its security from India. Pakistan's objective has also been to increase its power and strength in order to counter Indian position over Kashmir. It is also believed that Pakistan's nuclear capability would strengthen its bargaining power with the United States or the other powers to some degree ${ }^{6}$.

With these tests, India and Pakistan become the world sixth and seventh declared nuclear powers respectively, joining the USA, Russia, the UK, France and China. The tests conducted by India and Pakistan drew varying degrees of criticism across the globe. Some choose to freeze economic aid, some halted new development projects, while others favored discontinuation of multilateral credits. All of them, however, were united in condemning the nuclear explosions and appealed to both protagonists to sign the NPT. Realizing the fact that the main factor behind arms race in the region was the festering Kashmir dispute, advocated that the two protagonists should enter into a dialogue to try and resolve the issue peacefully. The sanctions, however, were expected to have a more debilitating impact on Pakistan than on India because Pakistan was more heavily dependent on international economic assistances. ${ }^{18}$

Similarly, the South Asian countries showed signs of anxiety over the nuclear tests by India and Pakistan. Begum Khalida Zia, leader of opposition in Bangladesh, reacted strongly and said that the nuclearization had endangered peace and stability in the region. Sri Lanka also expressed deep concern over the nuclear tests, followed by Nepal a small land locked country, and a signatory of NPT and CTBT also expressed apprehension over nuclear tests. Maldives was similarly unhappy about nuclear race in the region. President Abdul Gayoom of Maldives, who was the then Chairman of the SAARC, as a sign of protest postponed his customary visit to SAARC countries. He also impressed upon the SAARC countries the need to contain the situation arising in the region. The tiny Kingdom of Bhutan was the only country which congratulated India for its Bokhara II

${ }^{16}$. B.C Upreti, Contemporary South Asia, Op.Cit., p.119.

${ }^{17}$. Dawn, May 29, 1998

${ }^{18}$. Naveed Ahmed Tahir,ed, Pakistan and Post Ideological Europe: Prospect for Cooperation in the $21^{\text {st }}$ Century

Countries(Karachi: University of Karachi Press, 2000), p. 30. 
test. The Bhutanese King declared that Bhutan considers India as its closest friend and well-wisher and therefore increase in its power was in Bhutan's interest. ${ }^{19}$

\section{Pakistan as a Declared Nuclear Power: 1998 to the Present}

Soon after the nuclear tests, both Pakistan and India assured the world community in the Lahore Declaration (1999) that nuclear weapons would not fall victim to any strategic miscalculation of the two leaderships. The Lahore Declaration was a bilateral understanding between the two arch rivals to 'take immediate steps for reducing the risk of accidental or unauthorized use of nuclear weapons and discuss concepts and doctrines with a view to elaborating measures for confidence building in the nuclear and conventional fields, aimed at prevention of conflict'. The accompanying Memorandum of Understanding also called for limited transparency measures. Although these steps were not practically implemented, the Lahore Declaration, nevertheless, provided a foundation for limiting the threat of nuclearization and of initiating nuclear disarmament in the region. $^{20}$

On 17 August 1999, the Indian Nuclear Doctrine was released by Brajesh Mishra, the then Indian National Security Advisor in New Delhi. The Indian nuclear doctrine includes the following features:

1. India would maintain minimum nuclear deterrence ;

2. The basic aim of Indian nuclear weapons is to deter the use or any threat of use of nuclear weapon against India;

3. India would desist from using nuclear weapons against non-nuclear weapon states;

4. Retaliatory steps can only be authorized by the highest political leadership through the National Command Authority (NCA);

5. India's commitment is of no first use of nuclear weapons;

6. It would continue to observe the moratorium on further nuclear testing. ${ }^{21}$

Pakistan's thinking on nuclear strategy began to unfold in May 1998. Islamabad has never publicly elaborated its nuclear doctrine. Pakistan's doctrine becomes apparent through official press statements and interviews of officials. The main features of the doctrine are the following:

1. Pakistan's nuclear weapons are meant to deter aggression, whether conventional or nuclear;

${ }^{19}$. B.C Upreti, Contemporary South Asia, Op.Cit.,pp. 121-122.

${ }^{20}$.Effendi Maria Saifuddin,Pakistan-India Peace Process: Summits in Focus (1999-2005), Regional Studies, Vol. xxiv, No.3, summer, 2006, p.81

${ }^{21}$.Pervaiz IqbalCheema, ed, Arms Race And Nuclear Development In South Asia, (Islamabad: Policy Research Institute,2004), pp.85-86 
2. An integral part of Pakistan's security calculus is credible minimum nuclear deterrence;

3. Pakistan has not eschewed the first use option;

4. A unanimous decision for using nuclear weapons would be taken through the National Command Authority.

5. Pakistan would continue to support the concept of a nuclear free zone in South Asia.

6. Pakistan has agreed to a moratorium on nuclear testing, but would not sign the CTBT. $^{22}$

7. Pakistan does not abide by a no-first-use doctrine. ${ }^{23}$

\section{Pakistan and Nuclear Agreements}

India's record on nuclear non-proliferation is not very commendable. It refused to sign the NPT and justified its refusal by dubbing the treaty as discriminatory. Though ironically, it was India that had first proposed a NBT in 1954 and had adopted a constructive approach. ${ }^{24}$ Since 1974 India had consistently refused to sign nuclear proliferation treaties. New Delhi rejected the test ban treaty giving as it believed the treaty to be discriminatory. ${ }^{25}$ Moreover, if India signed the treaty, more pressure would be exerted on New Delhi to sign the FMCT and NPT whereas India's nuclear weapons program would need more tests for further advancement. Furthermore, after the rejection of CTBT by the American Senate, Washington has lost any moral ground to propagate that treaty. ${ }^{26}$

Unlike India, Pakistan has been a strong supporter of nuclear non-proliferation. Pakistan in the decade of seventies and eighties took some major initiatives to promote the cause of nuclear non-proliferation in South Asia, but unfortunately, India opposed these measures on various pretexts. India's attitude revealed the insincerity of its claims that its nuclear program was peaceful. It also showed that it was not truly committed to nuclear disarmament. In 1972, in the UN General Assembly, Pakistan for the first time, advocated the creation a NWFZ in the Indian Ocean. On other occasions, Pakistan proposed that both countries simultaneously accept full scope of International Atomic Energy Agency (IAEA) safeguards; that a mechanism be established for mutual inspection of each other's nuclear installations; both parties should issue a joint declaration renouncing the manufacture of nuclear weapons; the establishment of a NWFZ in South Asia; a conference to be convened under UN auspices (with the participation of all countries of South Asia) to discuss the matter of nuclear nonproliferation in the South Asian region; an Indo-Pakistan treaty to ban nuclear testing; and a five-power conference to discuss the nuclear issue in South Asia. To this conference, besides India and Pakistan, the US, Russia and China were also to be invited

${ }^{22}$. Ibid,pp. $87-89$

${ }^{23}$. http://www.fas.org/nuke/guide/pakistan/nuke/

${ }^{24}$. NaveedAhmed Tahir, ed, A Survey of EU-Pakistan Relations in the Contemporary Regional

\& International Setting: Political, Security, Economic and Development Aspects,Op.Cit.,p.117.

${ }^{25}$. Moonis Ahmer, ed, The CTBT Controversy ,(Karachi: University of Karachi Press, 2000) ,p.39

${ }^{26}$. Ibid, p.39 
to participate. Pakistan's moral position was strengthened when many of these proposals received overwhelming support in the UN. ${ }^{27}$ Between 1984-1986, Pakistan supported all ten resolutions on nuclear test ban in the UN General Assembly. It had voted for CTBT when the Assembly adopted it in 1996. However, the widely prevalent perception in Pakistan on the CTBT is that the country should not accede to the treaty unless India first does so. However, like India, important Pakistani perceptions on the CTBT are based on rejection, support and consensus. Those who are against adhering to the treaty put forth a three-pronged argument. First, if Pakistan signs and ratifies the treaty, then, the next aim of the US would be to force Islamabad to subscribe to the FMCT and NPT. The second argument is that Pakistan should not sign the CTBT as it requires further testing. Thirdly, CTBT has lost its credibility in view of rejection of the same by the US Senate. ${ }^{28}$

\section{Conclusion}

The nuclearization of South Asia is a matter of international concern, particularly since Pakistan and India have an adversarial relationship. Both possess medium-range missiles that would ensure the destruction of all the major cities in the two countries. War therefore, is no longer - or at least should not be an option. Therefore, issuance of irresponsible statements from both sides must be controlled as they pose serious threat for the use of nuclear weapons.

Critical evaluation of west's policy towards South Asian nuclear issue has some visible gaps between its avowed principles and actions and reveals dual standards. For instance, the west conveniently ignored the history of the Indian nuclear program and its ambition to gain a predominant position in the region. It is quite evident that the US and Europe were more anxious to halt Pakistan's acquisition of nuclear capability than they were about India's nuclear ambition which had become quite overt after its so-called (PNE) way back in 1974. The major western powers exerted maximum pressure on Pakistan to rollback or at least to freeze its nuclear capability, instead of trying to rein in India's nuclear ambitions. Likewise, not many efforts were made to assuage Pakistan's genuine security concerns, by at least promising help to achieve parity with India in conventional weapons and by collectively guaranteeing its security.

It should have been rather easy to distinguish between the respective motivations of Pakistan and India in conducting nuclear tests. Since independence and until the first nuclear tests by India in 1974, Pakistan did not seek nuclear option for itself. India, however, challenged the nuclear paradigm of the day, and willfully set its own nuclear ambitions. Pakistan, lacking strategic depth and lacking the resources to establish parity with its eastern neighbor in conventional weaponry, could no longer ignore the threat to its security. Therefore, developing a nuclear weapons program in the mid -seventies was only inevitable.

Ideally, after having demonstrated their nuclear capability, India and Pakistan could decide to voluntarily opt out of the 'nuclear option' and settle their bilateral disputes

27. Moonis Ahmer, Opcit, p.117.

${ }^{28}$. Ibid, pp.42-47 
and differences. This scenario, however, is not likely to materialize, in the near future. There are concrete examples of how other countries have settled disputes and reaped the enormous benefits of denuclearization. This could also bring a gleam of hope to the eyes of the masses of the subcontinent that have begun to believe in living with despair and poverty as their ordained fate. New initiatives in the paradigms of security and development are indispensable in South Asia. Without a bold vision and breaking away from the rancorous legacy of the past the subcontinent may not be able to survive the specter of nuclearization. 